\title{
Romeu e Julieta para crianças: tradução intersemiótica do texto dramatúrgico no espetáculo Mônica e Cebolinha no mundo de Romeu e Julieta
}

\author{
Romeu y Julieta para niños: traducción intersemiotica del texto dramatúrgico en el espectáculo Mónica y \\ Cebollita en el mundo de Romeo y Julieta
}

Tiago Marques Luiz

Centro Universitário Leonardo da Vinci - Uniasselvi - Santa Catarina - Brasil

\section{Fabiano Tadeu Grazioli}

Universidade Regional do Alto Uruguai e das Missões - URI - Rio Grande do Sul - Brasil

\begin{abstract}
Resumo: Considerando a tradução como uma operação semiótica entre linguagens, em que se coteja o processo de condensação e adequação de uma matriz textual para atender um determinado público, este trabalho tem como propósito fazer uma análise da tradução intersemiótica da peça trágica Romeu e Julieta, de William Shakespeare para o texto dramático Mônica e Cebolinha no Mundo de Romeu e Julieta, de Yara Maura Silva, com ênfase na cena do balcão, a mais conhecida e aquela considerada a alegoria do amor jovem. A partir das considerações iniciais e reflexões desenvolvidas, podemos pontuar que se valer de um produto cultural voltado ao público infantil - no caso, a Turma da Mônica -, como também apresentar um texto leve, carregado de rimas é um ponto de partida muito significativo para atrair a atenção da criança para conhecer um autor da literatura ocidental.
\end{abstract}

Palavras-chave: Tradução. Transposição. Romeu e Julieta. Turma da Mônica. Cena do balcão.

Resumen: Considerando la traducción como una operación semiótica entre lenguajes, en la que se compara el proceso de condensación y adaptación de una matriz textual al encuentro de un público específico, este trabajo tiene como objetivo analizar la traducción intersemiótica de la obra trágica Romeo y Julieta, de William Shakespeare para el texto dramático Mónica y Cebollita en el mundo de Romeo y Julieta, de Yara Maura Silva, con énfasis en la escena del balcón, la más conocida y considerada la alegoría del amor joven. A partir de las consideraciones y reflexiones iniciales desarrolladas, podemos señalar que utilizar un producto cultural dirigido a los niños -en este caso, Mónica y Su Pandilla-, así como presentar un texto ligero, cargado de rimas, es un punto de partida muy significativo para atraer la atención del niño para encontrarse con un autor de literatura occidental.

Palabras clave: Traducción. Transposición. Romeo y Julieta. Mónica y su pandilla. Escena de balcón. 


\section{Introdução}

O teatro é uma das artes que tem sabido expressar a individualidade humana e que, alicerçada em componentes como luz, trilha sonora, cenário e atores, entretém, desvela e ultrapassa fronteiras do texto dramatúrgico, sendo revisto e ressignificado ao longo do tempo. Provocado pela performance, este material verbal sempre está sujeito a novas releituras com vistas à novas montagens e adaptações a públicos variados, desde que o efeito desejado (riso ou comoção) seja atingido.

A obra de arte, tecida a partir de ideias, visões e invenções, motivou e continua a motivar leituras entusiasmadas e acalorados debates no espaço tênue que une leitores e pesquisadores da literatura e da arte dramática.

Em uma perspectiva cronológica, muitos textos sensibilizaram plateias, assim como há aqueles que foram malvistos nos palcos, no entanto, é preciso ter em mente que as discussões motivadas por um determinado texto, provém da esfera do sensível do autor, o indivíduo responsável em partilhar sua visão de mundo, ou seja, o texto dramatúrgico estabelece, por meio das palavras e das formas de sua organização "as interrelações vivas, específicas, do autor com o mundo que ele descreve, e entrando nessas interrelações como um terceiro participante (o papel do ouvinte)" (VOLOŠINOV, 1976, p. 12, tradução nossa $\left.{ }^{1}\right)$. O significado do próprio texto, segundo Martin Esslin (2002) também pode mudar com o tempo, podendo ele "se tornar uma peça de época à medida que a linguagem evolui e os conceitos e condições que descreve mudam" (ESLLIN, 2002, p. 26, tradução nossa ${ }^{2}$ ). E uma dramaturgia que tem sido simultaneamente preservada e modificada é a de William Shakespeare, que tem sido objeto de discussão desde o Renascimento.
As peças do dramaturgo de Stratford-uponAvon retrataram a individualidade do homem ocidental de sua época, no entanto, elas podem ser consideradas tão contemporâneas quanto: Romeu e Julieta, uma peça trágica, traz em seu núcleo a querela entre famílias inimigas, cuja razão - desconhecida por nós no texto - pode ser de ordem social ou política, servindo de pano de fundo para produções audiovisuais como Maré, nossa história de Amor (2007), por exemplo, que retrata o conflito entre facções criminosas pelo domínio da favela da Maré, no Rio de Janeiro.

Em nossa contemporaneidade, pouco se discute ou tem se discutido sobre como apresentar Shakespeare para um público alheio a ele: o infantil. Como o teatro, uma arte (geralmente) performada por adultos, cativa esse público ao encenar um texto denso como Romeu e Julieta, uma de suas mais aclamadas tragédias? Como traduzir esse conteúdo verbal pensando na dramaturgia escrita - para que ela seja recebida e desperte o interesse pelas escritas do dramaturgo inglês? Uma possível resposta seria: além do conteúdo veiculado, adjunto a ele, estão questões ideológicas que determinarão a recepção do público desejado, estabelecendo o que Hélio de Seixas Guimarães define como uma "zona de conflito entre as formas culturais diferentes, muitas vezes produzidas em tempos diferentes e voltadas para públicos também muito diferentes entre si e bastante heterogêneos" (GUIMARÃES, 2003, p. 110).

Nessa perspectiva, para este trabalho elencamos como objeto de pesquisa 0 texto dramatúrgico Mônica e Cebolinha no Mundo de Romeu e Julieta, escrito por Yara Maura Silva (1978 [1988³]), aproveitado como uma produção televisiva, a cargo dos diretores José Amâncio e Beto Mariano, filmada em Ouro Preto e exibido pela TV Bandeirantes em 1979. Mônica e Cebolinha no Mundo de Romeu e Julieta é uma paródia da peça trágica de Shakespeare,

Bandeirantes, como um especial em comemoração ao Dia Internacional da Criança. No ano de 1988, foi publicado o texto dramatúrgico no livro A Magia do Teatro Infantil, organizado por Arnaldo Niskier.

\footnotetext{
${ }^{1}$ No original: "living interrelations of the author with the world he depicts and entering into those interrelations as a third participant (the listener's role)".

${ }^{2}$ No original: "it can become a period piece as language evolves and as the concepts and conditions it describes change".

${ }^{3}$ Em 1978, houve a primeira encenação desse texto no Teatro TUCA, em São Paulo. No ano de 1979, foi veiculado na TV
} 
gravada no formato live action, com atores mascarados representando os personagens da Turma da Mônica, mas vale ressaltar que, embora sejam adultos representando crianças, as vozes são infantis, correspondendo a cada personagem de Mauricio de Sousa. O texto dramatúrgico de Yara Maura Silva e o referido programa ou "especial" exibido na televisão compõem o objeto de estudo deste trabalho.

Uma adaptação ${ }^{4}$ para a televisão de Romeu e Julieta é uma "tentativa de reproduzir" este clássico teatral, além de discutir a justificativa de sua produção para a televisão com os problemas de produção envolvidos. A justificativa dessa peça dramática ser redimensionada para a produção televisiva requer uma explicação detalhada dos fatores conhecidos que contribuem para sua reputação no mundo do teatro e do audiovisual, justificativa que procuraremos pontuar, pelo menos parcialmente, no decorrer desta escrita. Aclamada como a história de amor mais famosa do mundo, Romeu e Julieta tem uma história interessante desde o teatro - considerando a fixação do texto, portanto a dramaturgia escrita - ao cinema, bem como levanta discussões dos problemas na produção de dramas de Shakespeare na televisão em contraste com o palco e o filme, as quais refletem vantagens e desvantagens, conforme serão consideradas neste trabalho.

Além do exposto, este trabalho visa estimular a reflexão sobre o espaço que a teoria da tradução concede ao teatro e a televisão, e a refletir sobre o diálogo entre esses campos, através de fenômenos como a adaptação e a dramaturgia. Após a discussão, encerramos 0 artigo com algumas reflexões finais (embora não permanentes) sobre o tema de Shakespeare sobre as crianças, especialmente do trabalho da empresa.

A tradução do teatro ocorre através do deslocamento dos signos no tempo, no espaço e, consequentemente, na linguagem. Assim como qualquer tradução de determinada obra, o mesmo pode ser dito das adaptações entre linguagens, no sentido de que a intencionalidade de quem adapta não necessariamente partilha da mesma visão que o autor, logo, o texto de partida se insere em uma nova temporalidade - a do tradutor/diretor, proporcionando uma experiência diferente daquela de quando a obra foi produzida.

\section{Teatro, televisão e tradução: dramaturgia e ação}

Dentro do campo dos Estudos da Tradução, há uma corrente denominada tradução intersemiótica, cunhada por Roman Jakobson [2003], que consiste na transposição de um sistema de significante a outro, fenômeno esse conhecido como adaptação. A tradução intersemiótica é um processo que envolve a transição de um texto caracterizado por uma substância expressiva homogênea - em palavras para um texto em que coexistem substâncias expressivas heterogêneas, tanto visual quanto sonoro, como querem Anna Balogh (1996), Sandra Reimão (2004) e Flávio Campos (2019).

Em nosso texto, analisamos a tradução intersemiótica do texto dramatúrgico Mônica e Cebolinha no Mundo de Romeu e Julieta, de Yara Maura Silva para a sua versão televisiva homônima, portanto, estamos tratando de uma transposição do teatro para a televisão, ou seja, o verbal expresso em um conteúdo não-verbal. Ao se tratar da tradução de um suporte ao outro, é preciso levar em consideração que há um processo de recriação de textos-base em novos textos. No caso deste trabalho, estamos tratando de um texto dramático para o televisual, e um dos pontos ressaltados por Sábato Magaldi (1994) e Doc Comparato (2009) é de que ao adaptar e transformar a matriz textual em um novo formato, que sejam respeitadas as peculiaridades da nova linguagem. Podemos dizer que se trataria de uma transcodificação, como coloca Comparato (2009), no entanto, não é algo simples e que não pode ser reduzido apenas a esse deslocamento, pois transcodificar ou adaptar um conteúdo ficcional em audiovisual consiste em uma alteração, inicialmente, do meio para narrar aquela história e,

\footnotetext{
${ }^{4}$ No decorrer do texto, trataremos os termos transposição, tradução intersemiótica e adaptação como sinônimos
} 
consequentemente, da própria narrativa em si (COMPARATO, 2009, p. 290).

Como bem ressalta Campos (2019), dois pontos devem ser levados em consideração ao adaptar o teatro para a televisão, a saber: "a permeabilidade a que o espaço da estória seja expandido e à tradução visual do que narra", configurando uma obra autônoma (CAMPOS, 2019, p. 299, grifos nossos).

De acordo com Sarah Cardwell (2007a), falar de adaptação implica em uma comparação, em que se estabelece uma correspondência entre um livro e sua versão audiovisual pelo crivo da fidelidade, no entanto, essa suposta fidelidade não é o único parâmetro a ser utilizado para o trabalho de correspondência entre palavra e imagem. Linguagens como a televisão ou teatro veiculam uma informação de forma visível e sonora e existem elementos caros à essa transposição, como, por exemplo, a escolha de atores para interpretar determinados personagens da narrativa, a música, o cenário, a caracterização, entre outros.

Portanto, esta operação interlinguagens consiste em um entendimento por parte dos agentes da televisão em relação ao texto-base, em que "as partes em jogo [agentes e espectadores] deveriam experimentar uma sensação de razoável e recíproca satisfação, à luz do áureo princípio de que não se pode ter tudo" (ECO, 2007, p. 19, colchetes nossos). No que diz respeito à correspondência entre teatro e televisão, Patrice Pavis (2015, p. 397) pondera de que o teatro exerce um papel importante na televisão, o qual não pode ser negligenciado, até porque a televisão deve e muito de sua composição dramática ao teatro.

Uma das possibilidades de adaptar uma obra para o audiovisual é fazer uma aproximação com um público alheio à literatura, como se aquele produto televisivo fosse a obra em si, o que não é verdade, contudo, em decorrência da distribuição em massa, é visível, no mercado editorial, a venda crescente de títulos que deram origem aos programas televisivos, todavia, ao consultar essa matriz literária ou dramática, o público atraído pela programação veiculada atribui um valor depreciativo "em relação à interpretação da obra literária[/dramática] que a telenovela apresenta para milhões de telespectadores." (GUIMARÃES, 1995 , p. 133, colchetes nossos), ou seja, a programação televisiva impõe um "valor literário" à essa literatura e não ao texto escrito em si, observando aqui uma retroalimentação nada favorável ao textobase. A partir de Guimarães, nota-se que o texto literário é tido como algo obsoleto, pois parte-se do preceito de que assistir ao programa televisivo equivale a ler o livro, no entanto, existem duas questões delicadas em jogo ao falar de adaptação a televisão: "1) reforçar o valor atribuído ao texto escrito entre aqueles que têm acesso a ele; 2) introduzir esse valor para aqueles que não têm acesso a ele", por meio da televisão (GUIMARÃES, 1995, p. 142).

Há uma linha tênue sobre o que é o teatro como àquele que veicula no palco e o veiculado na televisão: o primeiro, chamado de literário, é o textocêntrico, ou seja, aquele que tem como foco a modalidade textual, ao passo que o outro, denominado cenocêntrico, é "descentrado e desconectado da realidade mimética. É essa diferença que melhor esclarece as mudanças da nossa maneira de perceber o mundo" (PAVIS, 2003, p. 41). A adaptação de obras narrativas apresenta uma ampla gama de problemas, e muitas explicações e possibilidades têm sido propostas, permitindo inferir que, ao longo do tempo, várias histórias foram contadas e contadas inúmeras vezes.

É possível traduzir intersemioticamente o teatro para a televisão, no sentido de que o texto-base, mesmo que ele não faça "o papel de pólo de atração para o resto da representação", o qual pode ser atualizado, ressignificado e encenado, potencializando um dos inúmeros significados que a obra literária/dramática permite inferir, dando a entender que cada veículo tem seus "critérios de dramaticidade (maneira de armar um conflito) e de teatralidade (maneira de utilizar a cena)" (PAVIS, 2003, p. 194).

Por tradução do conteúdo dramático ao visual, Pavis o nomeia como adaptação, cuja natureza é transpor o diálogo dramático ou do romance por meio de "diálogos (muitas vezes diferentes dos originais) e sobretudo em ações cênicas que usam todos as 
matérias da representação teatral (gestos, imagens, música etc.)" (PAVIS, 2015, p. 10). Em outras palavras, se trata de uma redimensão do conteúdo-fonte em um novo formato, marcado pela perspicácia e criatividade, em que se configura determinada metalinguagem, isto é, a linguagem teatral traduzida para a televisiva, podendo o texto-base ser apresentado de muitas maneiras, como por exemplo, pelo olhar do protagonista e/ou do antagonista, conforme o projeto de roteirização do diretor.

Nota-se que a correspondência entre literatura e televisão vem permeada pelo viés da fidelidade, como se o texto literário fosse imutável ou estático e que caberia aos agentes do audiovisual demonstrar respeito e a melhor representação do mesmo, no entanto, felizmente, um dos vieses adotados, benéfico a ambos os lados, é ver em que medida a televisão interfere na obra-base.

De acordo com Cardwell (2007a), existem duas faces sobre a adaptação: a melhor delas é intrínseca ao texto-base, ou seja, por conhecermos determinada obra literária, há um horizonte de expectativas de que determinada adaptação representará visualmente tão bem o texto escrito. Nas palavras da autora, por conhecermos a obra, ela vai moldando "nossa recepção da adaptação, levando-nos a focar muito estreitamente alguns aspectos em detrimento de outros e ignorar outros fatores contextuais relevantes" (CARDWELL, 2007a, p. 52, tradução nossa ${ }^{5}$ ). Em contrapartida, a pior das hipóteses é vermos que, por ser uma adaptação, atribui-se um valor negativo à mesma, por conta da tendência de considerarmos essa obra audiovisual muito inferior ao conteúdo escrito. Como bem constata a autora, tanto a interpretação como a avaliação "são afetadas, e nossa atenção atenta ao filme como obra de arte é reduzida" (CARDWELL, 2007a, p. 52, tradução nossa ${ }^{6}$ ), e que haja cautela com as categorias de tempo, ação e espaço, de modo que não venha a se destoar tanto do conteúdo-base, podendo expandir determinados detalhes - como a atmosfera da narrativa, por exemplo - de modo mais concreto.

${ }^{5}$ No original: "our reception of the adaptation, leading us to focus too narrowly on some aspects over others and to ignore other relevant contextual factors"
A pauta da temporalidade da repetição envolvida na tradução intersemiótica e as ideias de progressão e retorno são aspectos de como a adaptação está conectada à historiografia, contudo, é preciso considerar que a ideia de adaptar uma obra não deve ter como ponto de partida a extensão da obra - no caso de livro, as centenas de páginas -, até porque, como bem ressalta Flávio de Campos (2019), adaptar consiste na "transposição de uma estória para outro tempo, lugar, formato ou gênero" (CAMPOS, 2019, p. 293). Logo, não se pode esperar uma integralidade do conteúdo verbal, até porque é uma via de mão dupla ao tratar da extensão da obra adaptada, ou seja, adaptar na condensação do texto-base "para pouco mais de uma centena de páginas de roteiro. Por outro lado, adaptar livro para novela de tv implica expandir as poucas centenas de páginas do original para os milhares de páginas de roteiro" (CAMPOS, 2019, p. 295)

Verticalizando a teoria da tradução intersemiótica, acerca da correspondência entre teatro e televisão, em que um texto dramático será redimensionado para o formato audiovisual, Sábato Magaldi (1994) já tecia a observação de que não se questiona o teor adaptável do teatro para a televisão e pontua que é preciso que a transposição do texto dramático esteja atenta à estética da televisão, pois há peças "também filmadas ou televisionadas, sem o abandono dos métodos teatrais, não obstante o veículo diferente estivesse a reclamar uma recriação completa nos seus meios" (MAGALDI, 1994, p. 11). Uma possível distinção que pode ser feita entre teatro e televisão é que, no primeiro, cada encenação é única, e a vantagem que o palco oferece ao espectador também a é, pois naquele momento há uma comunicação direta entre ator e público. A televisão, por sua vez, impossibilita repetir a interação instantânea, tornando a fruição da experiência totalmente individual e hipoteticamente comovente (MAGALDI, 1994).

Como forma de sintetizar a ideia de adaptar Shakespeare para a televisão, recorremos a Schafer,

\footnotetext{
${ }^{6}$ No original: "are therefore affected, and our attentive responsiveness to the film as an artwork is reduced".
} 
que conceitua a adaptação das peças do dramaturgo como "um processo combinado de transferência e edição do roteiro do drama completo de Shakespeare para um formato com roteiro, produzido para a televisão" (SCHAFER, 1966, p. 3, tradução nossa7). E entrelaçar a mídia audiovisual com a dramaturgia significa levar em consideração o modo como a televisão apreende os temas e estruturas do texto dramático, como bem ressalta Magaldi (1994).

\section{Shakespeare para crianças: a tradução intersemiótica de Romeu e Julieta pela Turma da Mônica}

O público infantil é alheio a William Shakespeare, uma vez que ele não o pensava como frequentador de seus espetáculos, e vice-versa, dado o fato de que suas peças não retratavam crianças como protagonistas ou personagens que integravam o rol de dramatis personae. No caso de Romeu e Julieta, uma tragédia que tem como personagens-título dois pré-adolescentes, com um enredo denso e complexo acerca das relações sociais e de poder, não seria bem vista por esse público, porque se pensarmos na superfície da história, temas como a querela de famílias inimigas, suicídio e amor são temas ainda alheios à criança.

E afunilando nosso olhar para a peça, é desafiador representar um núcleo marcado pelo autoritarismo patriarcal (Senhor Capuleto), a falsidade (a Ama ao desdenhar Romeu perante o sofrimento de Julieta), o dogma da religião (Frei Lourenço casando os personagens-título em segredo), que levaram à autodestruição dos protagonistas, pelo extremo do suicídio. Além dessa teia complexa de temas que se inter-relacionam, a problemática de traduzir Shakespeare para o público infantil se deve, primeiramente, ao fato de criar uma nova versão, mediante o vasto legado de outras produções do mesmo texto do dramaturgo inglês, como também pela "reverência excessiva" de seus textos (RAUEN, 2005, p. 369), o que causaria desconforto para a suposta "essência" do texto-base.

Segundo Célia Arns de Miranda (2008), interpretar uma obra de Shakespeare consiste em condensar determinados aspectos de seus textos e ampliar outros, até porque, mesmo que haja inúmeras produções de uma mesma obra, o texto dramático sugere inesgotáveis releituras, e que cada espetáculo "provê apenas um insight parcial e nenhuma produção, não importa o quão definitiva possa ser, pode realizar todas as potencialidades do texto" (MIRANDA, 2008, p. 2).

Com base na posição de Miranda (2008), a visão teórica sobre o surgimento das obras de Shakespeare nos séculos XX e XXI sustenta que as novas obras não devem tentar "copiar" o texto original de Shakespeare, mas criar um novo dramaturgo. Essas novas produções não apenas percebem o potencial sem precedentes do texto básico, mas também expressam esse potencial de acordo com o novo ambiente de produção e recepção e por meio de novos motivos, como a ideologia, estética e cultura, o que significa dizer que, nesse processo de dar nova vida a obras de arte anteriores, mudanças ocorrem em novas situações e ambientes, e o resultado é "algo novo e híbrido" (HUTCHEON, 2013, p. 202). Por fim, na tarefa de apresentar o bardo para o público infantil, é preciso maior grau de criatividade perante seu texto, pois "as peças de Shakespeare almejaram, inicialmente, o público adulto e, portanto, exigem um novo olhar para serem recriadas ao público infantil" (SANFELICI, 2016, p. 155).

O texto shakespeariano fornece indicações de como ser transposto para o palco; enquanto lemos as suas narrativas, de modo inconsciente, traduzimos visualmente as ações das suas personagens, com suas respectivas falas, gestos, além do cenário em que se concentra a narrativa teatral. Quanto ao cotejo entre a representação no palco e a representação na televisão, a experiência catártica é potencializada, já sinalizado por Aristóteles em sua Poética e repetido

\footnotetext{
${ }^{7}$ No original: "a combined process of transferring and editing the script from Shakespeare's complete drama to a scripted format producible for television."
} 
interminavelmente até hoje, ao passo que na televisão, a catarse seja menos vigorosa.

Aimara da Cunha Resende (2016) nos diz que transpor o teatro de Shakespeare para a televisão demanda uma primeira consciência a respeito do mito Shakespeare, e a segunda a respeito do ambiente ao qual seu texto será ambientado, resultando "em uma renovação que, bem feita, permite o surgimento, em outro meio de comunicação, de uma obra recriada que pode ser muito rica, e de uma releitura que permite a continuidade do cânone" (RESENDE, 2016, p. 180).

O teatro infantil, como ramo da arte dramática, não fugiu à regra, pois enquanto processo criativo "alimenta-se tanto de criações individuais quanto do aproveitamento de material que circulou preliminarmente em outros contextos" (ZILBERMAN, 2015, p. 18). Em termos estruturais, as peças infantis são expressas, em sua maioria, em um único ato, por meio de "diálogos, que apresentam alguma ação desempenhada por personagens, com início, meio e fim" (ZILBERMAN, 2015, p. 19). Sobre apresentar William Shakespeare para esse público, a sugestão é de que seu texto seja "ressignificado para crianças, com qualidade, leveza e originalidade" (SANFELICI, 2016 , p. 150). No caso de adaptar um texto para a criança, é preciso atentar-se e compreender "seu universo e, em nenhum momento, deve-se rebaixar ao estereótipo de bobagem" (MENDES, 1988, p. 12).

Conforme explicado por Bárbara Heliodora (2007), o teatro infantil é marcado pela "Temática adequada, linguagem simples e acessível e aproveitamento dessa coisa maravilhosa que é a imaginação da criança" (HELIODORA, 2007, p. 193), e ressalta para que a companhia teatral não tenha receio de mudá-lo e molda-lo para que os espectadores infantis possam fruir de sua encenação. Além disso, podemos seguramente afirmar que a tradução intersemiótica do teatro para a televisão consiste não somente de um redimensionamento do palco para a tela, "mas também de uma escrita, de um estilo, de uma cultura, de uma sociedade e de uma singularidade" (PASSOS, 2011, p. 14).

Em Obra aberta, Umberto Eco delineia a "obra literária como contínua possibilidade de aberturas, reserva indefinida de significados", por conseguinte, dependente da inventividade e da sensibilidade do leitor (ECO, 1991, p. 47). Pode-se supor que esse tipo de "abertura" é uma característica de toda arte, pois essa polissemia torna-se possível quando há lacunas que precisam ser preenchidas - essas lacunas estão estrategicamente distribuídas em suas obras de grandes escritores, e estão diretamente relacionadas com a capacidade da arte se renovar, com um novo olhar, interpretação e, consequentemente, novos significados.

Qualquer obra de arte, embora não se entregue inacabada, exige uma resposta livre e inventiva, mesmo porque não poderá ser realmente compreendida se o intérprete não a reinventar num ato de congenialidade com o autor (ECO, 1991, p. 41).

Assim, pode-se dizer que Yara Maura Silva propõe uma repetição de Romeu e Julieta, com certo distanciamento, da mesma forma que enfatiza a diferença ao invés da semelhança. O texto dramático de Silva (1988) é um exercício criativo, como também um produto oriundo da tradição brasileira de adaptar Shakespeare em ambiente tropical, pois segundo Marcel Silva (2013), tanto os anos 1970 como os anos 1980 e em diante estão marcados de ressignificações dessa peça shakespeariana, permitindo dizer que existe um confronto estilístico entre as duas vozes (Shakespeare e Mauricio de Sousa), que, combinadas, resultam em uma "recodificação moderna que estabelece a diferença no coração da semelhança" (HUTCHEON, 1985, p. 19), que denominou-se de paródia, a qual toma para si as convenções de um período anterior e Ihes dá novas interpretações, possibilitando um enlace intertextual entre dois tipos de textos, em que um é atualizado e ressignificado no novo texto, permanecendo reconhecível.

A comédia em Shakespeare presenteia o espectador com uma série de intrigas que vão se complicando no desenvolvimento da trama, e que só são resolvidas com o final feliz e satisfatório a todos os envolvidos. A peça Romeu e Julieta, é permeada de diálogos cômicos, principalmente aqueles marcados pelos personagens Mercúcio e Ama, que se valem de linguagem vulgar, para representar o baixo corporal e 
a própria sexualização do tema do casamento ou da própria solidão - no caso da solidão, é quando Romeu sofre por Rosalina e para superar essa dor, Mercúcio aconselha o amigo a arranjar outra mulher ou sugerir a masturbação.

A comédia consiste em um "espirituoso diálogo e também, talvez, no fato de os protagonistas serem suficientemente inteligentes para se darem conta das tolices e dos absurdos das outras personagens e até de seus próprios" (DANZINGER; JOHNSON, 1974, p. 148). Das inúmeras categorias que provem da comédia, podemos categorizar o nosso objeto de pesquisa audiovisual como uma comédia romântica, cujo cerne é uma intriga amorosa e cujo desfecho consiste no castigo a outro personagem, como é o caso do Príncipe Xaveco de Verona, que baniu Lomeu ao exílio e foi castigado com uma coelhada de Julieta Monicapuleto.

Em relação à Mônica e Cebolinha interpretando Romeu e Julieta, há uma combinação das características de cada personagem para deixar o texto televisivo mais interessante, como as implicações entre os personagens de Mauricio de Sousa, predominantes nas histórias em quadrinhos, os planos infalíveis de Cebolinha e a força hercúlea de Mônica. Essa combinação de representar um texto clássico tem como objetivo motivar o interesse das crianças por autores imortais, como uma simbiose.

Um aspecto que podemos ressaltar sobre Romeu e Julieta ser uma peça adaptável, é porque seus personagens têm uma dinâmica muito rápida no desenvolvimento da trama, e pensando na cena do balcão (II, ii) a ser veiculada, seria preciso um cenário que representasse a interação que ali existe entre os protagonistas. Nesta cena em especial, o enquadramento precisaria ter um enfoque ou em cada personagem à medida que eles forem dialogando, por meio da técnica do zoom ou do close, ou no plano todo, para que o espectador possa ter uma dimensão do que é esse espaço e o que está acontecendo ali. A cena do balcão se consagrou devido à sua poesia e pelo romantismo nela presente, como também pelo modo como Shakespeare estabelece a dialética do amor nas palavras de Julieta, que anseia estar com Romeu, assim como adverte cautela por conta do sobrenome de sua família. Do jogo entre o dia e a noite, a linguagem poética dos jovens protagonistas representa o desejo de ambos, a contemplação de Romeu perante a figura de Julieta. Podemos considera-la como o divisor de águas da peça, pois ali estão concentrados o amor e o núcleo da peça, cujo enfoque retrata essa querela entre ambas as famílias, assim como nos mostra a medida extrema que os personagens tomam, que é casar em segredo e simultaneamente recusarem seus sobrenomes malditos em prol da união eterna.

$\mathrm{Na}$ transposição para a televisão pela Mauricio de Sousa Produções, foi utilizada a Igreja de São Francisco de Assis, cujo pisos superiores nos remetem ao quarto de Julieta, de um lado, e o de seus pais, do outro, cômodos representados pelas janelas em verde, ao passo que a sacada (outro nome dado à essa famosa cena da peça trágica) está ali representada a frente da janela do quarto de Julieta situado à direita -, para que ela possa se apoiar, ao declamar o seu famoso monólogo sobre a identidade de Romeu.

Comparar texto dramático e sua versão audiovisual incorre em questionar o papel da suposta fidelidade, uma vez que o título ressalta essa problemática - no mundo de Romeu e Julieta -, logo, supor que existe uma tradução intersemiótica "fiel" ao texto-base é incorrer em incertezas, pois essa temática suscita perguntas de natureza estilística do texto-base, como o diálogo, os personagens, caracterização, etc. Em nosso objeto de pesquisa, seguramente temos a presença do cômico das palavras, devidamente reconhecidas pelas figuras de linguagem, como a ironia, o jogo de palavras, o quiasmo - antítese invertida -, o quiproquó, entre outras. Além do cômico das palavras, temos o cômico da mecânica bergsoniana, ou seja, é a própria expressão fisionômica do ator que lhe confere o status de cômico e desencadeia a gargalhada para uma plateia. A comicidade de palavras, como o próprio nome sugere, é a manifestação do cômico através do texto, que dão indícios, nas palavras de Henri Bergson, de uma ação engraçada. Para conceituar essa comicidade, Bergson 
propõe algumas estratégias para que esse elemento cômico seja potencializado: a inversão do sentido literal pelo figurado, uma palavra repentina em uma frase - trocar um ditado popular -, a própria ambiguidade das palavras, a ironia e o humor. $O$ cômico pode ser, via de regra, essa justaposição de contrastes e opostos.

Para o filósofo francês, tal efeito cômico é desencadeado por conta de dois segmentos: o interno e o externo. $\mathrm{O}$ interno diz respeito ao espírito e à alma, onde o sujeito é suscetível à mudanças de estado, ao passo que o segundo segmento está vinculado ao corpo e as expressões desse corpo, ou seja, aquilo que é mecânico, na acepção de Bergson, e é justamente essa sobreposição de um sobre o outro é que temos o riso. A título de exemplo, podemos aplicar essa concepção em Julieta Mônicapuleto: o interno diz respeito ao seu estado psicológico e emocional que vive transitando de um romantismo para uma ira, enquanto o externo é representado pelos gestos e tom de voz da personagem, que nos é apresentada como uma personagem apaixonada, mas que contrariada pelo seu amado Romeu Montéquio Cebolinha, resolve tudo na base da coelhada (gesto agressivo, porém risível) ou no próprio tom intimidador (expressão do corpo, mais precisamente o aparelho vocal).

No quesito do humor, é totalmente visível que a criança rirá na adaptação, pelo fato de que as narrativas da Turma da Mônica são carregadas de muita comicidade, como os planos infalíveis de Cebolinha e Cascão que nunca dão certo, a distração da Magali com o pensamento em comida e a Mônica batendo nos meninos com o Sansão. Além das travessuras entre os personagens Mônica, Cebolinha, Cascão e Magali, temos a presença da música, carregadas de muitas rimas, com o intuito também de incentivar a criança a criar poesia e ter suas próprias rimas, com um vocabulário muito simples e de fácil compreensão para o aspecto cognitivo da criança.

A comédia, ao contrário da tragédia, suscita uma prazerosa relação com o espectador por ter o domínio imediato das situações que são desencadeadas, isentando o espectador da catástrofe que aflige o herói, e como o texto teatral tem uma nova releitura ao longo do tempo, é possível observar "quais os elementos que foram acrescentados e quais os subtraídos, quais os artifícios mais comuns na trajetória do tema e quais as recorrências na trama dos fatos" (BENDER, 1996, p. 16). E sobre a paródia como elemento que suscita a comédia, Resende vai propor que, ao ironizar o texto canonizado, ela reverte a suposta seriedade daquilo que é tido como verdade irrefutável "e traz à luz a alegre relatividade que desestabiliza o poderio hegemônico, qualquer que seja ele" (RESENDE, 2016, p. 182).

\section{Análise comparativa}

Na cena do balcão, vemos Lomeu Montéquio Cebolinha nos levando a uma varanda do castelo Capuleto, dizendo "E lá vou eu pala a famosa cena da sacada". Esse intertexto trazido por Cebolinha, como também pelos demais personagens do espetáculo, só vem confirmar a ideia da paródia como uma história que se repete de forma contínua. E o Montéquio continua o seu aparte com o telespectador:

ROMEU: E lá vou eu pala a famosa cena da sacada

"Selá" que é por aqui?

Oh, uma escada

Só espelo que Julieta esteja "acoldada" Se não, já "imaginalam" que mancada? E o pior é que estou perdendo o filme da "madlugada" (SILVA, 1988, p. 137)

A comédia nesse fragmento do espetáculo está no seu humor verbal. É madrugada e todo mundo foi embora do baile dos Capuletos, exceto Romeu. Para que não faça barulho, ele vai descendo os degraus cuidadosamente, contudo, no momento em que fala que está perdendo o filme da madrugada, o seu tom de voz é de alguém chateado por estar abrindo mão de uma programação interessante para se encontrar com Julieta. E quando ele chega na entrada do castelo, a porta está trancada. A cena da sacada está no Ato II, Cena II, e é marcada pelas juras de amor entre os protagonistas. No espetáculo infantil feito pela MSP, a cena é marcada pelo jogo de birra de criança: Julieta se declara para Romeu, ao passo que ele não corresponde de imediato, deixando-a zangada. 
Vemos Julieta na sacada de sua casa, procurando por Romeu, pronunciando seu nome em um ronronar de gato. Esse fragmento é visto como engraçado, porque a Julieta interpretada pela Mônica está chamando pelo seu amado em um tom fora do usual, como também distante do tom usado pela protagonista shakespeariana. Romeu escuta a sua amada chamando por ele, e ao invés de the responder amorosamente o chamado de Julieta, ele quebra o encadeamento romântico com a seguinte pergunta: "Será que ela não enxelga?". Irada porque ele não responde o seu chamado, ela já muda o tom de voz:

JULIETA: Romeu, onde estás que eu não o acho? ROMEU: Xi, qualé, ó doce Julieta, não vê que estou aqui embaixo? (SILVA, 1988, p. 137)

Logo após a pergunta do jovem Montéquio para a sua amada, começa a canção intitulada Cena do Balcão, onde podemos considerar os versos de Mônica como modulação dos seguintes versos de Julieta no texto-fonte

Tabela 1: Paráfrase da Cena do Balcão

\begin{tabular}{|l|l|}
\hline Cena do Balcão - & Cena do Balcão - Peça \\
Canção (SILVA, 1988, & (SHAKESPEARE, 1997, p. \\
p. 137-138) & 39) \\
\hline MÔNICA & JULIETA \\
Se você não puder & É só seu nome que é meu \\
Por amor a mim & inimigo: \\
Deixar de ser um & Mas você é você, não é \\
Montéquio & Montéquio! \\
Cebolinha & O que é Montéquio? Não é \\
Nosso amor chegará ao & pé, nem mão, \\
fim & Nem braço, nem feição, \\
Mas se assim não for & nem parte alguma \\
Tenho algo a propor & De homem algum. Oh, \\
Não sou mais Julieta & chame-se outra coisa! \\
E sim o seu amor & O que há num nome? O \\
CEBOLINHA & que chamamos rosa \\
Teria o mesmo cheiro com \\
Ouça isso Julieta & outro nome; \\
Eu quelo subir aí & E assim Romeu, chamado \\
Mas a coisa está pleta & de outra coisa, \\
Pois não da pla sair & Continuaria sempre a ser \\
daqui & perfeito, \\
Puxe essa tlepadeila & Com outro nome. Mude-o, \\
Pois não dá para sair & Romeu, \\
daqui & E em troca dele, que não é \\
Parece até blincadeila & você, \\
Minha capa está presa & Fique comigo. \\
no espinho & \\
\hline
\end{tabular}

Fonte: elaboração pelos autores.
A referida canção traz em sua letra o romantismo de Julieta, contraposta a trapalhada do Romeu, que está com a capa presa num espinho. Em gêneros musicais, temos uma entonação romântica nos versos de Julieta, enquanto Romeu canta seus versos em um foxtrote, interpondo um contraste aos versos de Julieta, tanto no ritmo mais ligeiro, quanto na letra da música. A partir das canções que apresentam os protagonistas ao espectador (Tema de Julieta e Sou o Lomeu), é possível que o estilo musical demarca a caracterização do personagem - Mônica é ríspida e exigente, enquanto Romeu é um malandro, mesmo que ingênuo. Logo após a fracassada declaração de amor entre Mônica e Cebolinha, o jovem consegue tirar a capa do espinho, mas vai ao chão. Devido ao uso da interjeição de dor "Ai", Mônica usa a onomatopeia "Shhh" para que ele não fale tão alto:

JULIETA: Precisava cair com toda essa barulheira? Tá querendo acordar todo mundo? Seu desastrado!

ROMEU: Não "plecisava" sacudir a "tlepadeila" com toda sua "folça". Como é que eu vou subir no seu balcão "agola"? JULIETA: Não interessa. E suba logo antes que eu perca a paciência. Olha que você apanha!

ROMEU (zangado, gritando): Mas subir de que jeito, sua mandona? Tá pensando que eu sou o "Homem-Alanha"? (SILVA, 1988 p. 138)

Esse momento traz uma sequência de quiproquós, com a jovem Capuleto mandando o Montéquio subir a sacada, mas ele não consegue, enfurecendo mais ainda a jovem. Romeu traz o intertexto do Homem-Aranha, um super-herói contemporâneo da Marvel conhecido pela sua habilidade de escalar, contudo Romeu se compara ao super-herói, por não ter essa habilidade e atender à exigência de Julieta. No texto-fonte, Romeu tem um discurso rebuscado, carregado de epítetos e figuras de linguagem, como o trecho abaixo que encerra a cena do Balcão:

\section{ROMEU}

Tenha sono em seus olhos, paz no seio; Por sono e paz tão doces eu anseio. Sorri a aurora ao escuro pesado, No leste, a luz já deixa o céu rajado; O negror, ébrio, corre pra escapar Das rodas de Titã, que vai passar. Vou à cela do pai da minha alma, 
Pra falar disso e ter ajuda e calma. (Sai.) (SHAKESPEARE, 1997, p. 73)

Voltando ao texto do espetáculo infantil, após evocar o intertexto do herói da Marvel, Julieta lhe pede que não fale tão alto, pois o seu pai pode acordar, porém, Romeu não consegue escutá-la:

\author{
JULIETA: Não fale tão alto senão meu pai \\ acorda! \\ ROMEU: O quê? \\ JULIETA: Não fale tão alto senão o meu \\ pai acorda! \\ ROMEU: O queeeee? \\ JULIETA: Não fale tão alto senão o meu \\ pai acooorrrrrrrdddddaaaaa! \\ ROMEU: É isso aí. \\ JULIETA: Isso aí o que? \\ ROMEU: A "colda"! Jogue a "colda", "pala" \\ eu subir aí na sacada! "Vilam" só que \\ sacada genial? (SILVA, 1988, p. 138)
}

Este fragmento da conversa entre Julieta e Romeu é marcado pela paronomásia entre "Acorda" e "A colda", devido à dislalia do Cebolinha, que ao invés de entender o verbo como um despertar, entendeu como objeto. Além dessa paronomásia entre as classes gramaticais, temos também a ambiguidade proposta em "sacada", que vai remeter tanto ao espaço onde Julieta se encontra, como também se entende "sacada" como sinônimo de ideia, ou, fazendo um intertexto com as narrativas de Cebolinha, um plano infalível.

Julieta vai jogar a corda para que seu amado suba, porém, nas primeira e segunda tentativas, não é o suficiente, pois Romeu lhe pede para jogar mais. $\mathrm{Na}$ terceira tentativa, seu tom de voz já muda, de curiosa para impaciente. E quando ele afirma que a corda atingiu um limite ideal para que ele possa subir e ela puxá-lo com sua força, o Senhor Capuleto acorda com o barulho. Depois de ouvir o pai de Julieta perguntando que barulho era aquele, Julieta solta a corda desesperada, para frustração de Romeu. Para responder o questionamento do Senhor Capuleto, Cebolinha assobia como um pássaro, por meio da onomatopeia "Piu".

Ao reconhecer 0 som, Senhor Capuleto questiona se é "a cotovia que anuncia o dia", e Romeu Ihe responde que não, imitando novamente o som do pássaro e lhe diz que é "o louxinol do alebol, que está deixando o ninho". Como bem pontua Marcel Silva
(2013), essa cena do balcão de Mônica e Cebolinha interpretando Romeu e Julieta é vista como um momento de explosão cômica, cujo emprego das imagens do rouxinol e da cotovia, representando o ápice da noite ou raiar do dia é expresso em jogo de palavras por conta da dislalia de Cebolinha, modificando os sentidos dramáticos da cena.

O senhor Capuleto, conformado com a resposta recebida, encerra que pode dormir mais cinco minutos, e volta a dormir, emitindo um ronco estrondoso. Cabe enfatizar que a evocação do rouxinol e da cotovia surge somente no Ato III, Cena V do texto-fonte, cena essa onde Romeu é condenado ao exílio pela morte de Teobaldo - primo de Julieta - e passa a primeira e única noite.

O espetáculo televisivo propõe uma combinação da referida cena do terceiro ato com a cena do balcão, trazendo elementos que estão devidamente separados na peça original. A gestualidade, tão cara à linguagem teatral também se faz presente, pois logo que o Senhor Capuleto volta a dormir, Julieta diz a seu amado que precisa entrar, sinalizando com a mão e apontando para o quarto do Capuletão. Triste e inconformado com a partida de sua amada, ele a pergunta:
ROMEU (declamando): Como posso ir sossegado se estou apaixonado?
JULIETA: Se é o que você deseja, me espere amanhã na igreja.
ROMEU: Por que na igreja? Espere um momento.
JULIETA: Para o nosso casamento.
ROMEU (Gritando): Casamento? Mas quem falou em casamento?
JULIETA: Nós... (Julieta entra)
(Já é dia. Romeu vai saindo. Frei Cascão vem chegando) (SILVA, 1988, p. 139)

Quando se fala em adaptação de uma obra, é importante ressaltar que o mesmo conteúdo, apesar de possuir abordagens diferentes no decorrer de suas narrativas, não deixa de conter o enredo original, isto é, se demonstra que, apesar da abordagem ser direcionada, não se fugiu de um determinado padrão percebido no texto-base. No caso de Romeu e Julieta pela ótica de Yara Maura Silva, nota-se que o texto shakespeariano foi modificado para se tornar mais acessível ao público-alvo escolhido. Além da acessibilidade à obra, existe uma retroalimentação 
entre a Literatura e a televisão, visando o mercado de massa, em que um fomenta o consumo do outro, atraindo o público desejado.

Observa-se que Yara Maura teve o cuidado de deixar em evidência a personalidade dos seus personagens na cena do balcão, sem distanciar-se do que essa cena significa na peça original, pressupondo que o público já tivesse um pré-conhecimento sobre o texto a turma que iria encenar, a começar pelo título: no mundo de Romeu e Julieta, evidenciando o caráter intertextual que Mauricio de Sousa traça na construção dessa adaptação televisiva. Analisando a cena do balcão se percebe a presença do humor característico de uma grande parcela dos produtos culturais destinados à infância, mas conservando propriedades da peça Romeu e Julieta. Se confrontarmos com a edição aqui utilizada, uma tradução de Bárbara Heliodora publicada em 1997, observa-se que não há a quantidade de rimas como possui na cantiga e em alguns diálogos do Cebolinha no decorrer da apresentação; podemos dizer que isso foi um dos artefatos da produção para manter uma estética interessante e um bom desenvolvimento, a fim de se atingir o público infantil.

Repleta de emoção, a cena do balcão foi concebida no espetáculo para transmitir alegria e reflexões em suas comparações, com rimas que evidenciam a ideia do autor, a de transformar um texto adulto acessível e compreensível a todas as idades. Em outras palavras, a paródia traz em si a particularidade do riso, de despertar os sentimentos, um artifício cômico e lúdico ao mesmo tempo. Ela é uma construção carregada de muitas doses de ironia, como vemos no verso de Lomeu: "Ouça isso Julieta, eu quelo subir aí, mas a coisa aqui tá pleta, pois não dá pla sair daqui, puxe essa tlepadeila, ajude o seu Lomeuzinho, até palece blincadeila, minha capa está plesa num espinho". (SILVA, 1988, p. 137-138).

No ato da adaptação ou no recontar um clássico, pode ser necessário dar um enfoque e outra atribuição de valor, uma vez que, por trás dessa paródia e desse recontar, há uma autoria que conduz o espetáculo em toda sua particularidade, de modo diferente e especial, e mesmo que supostamente o vínculo à essa história seja algo considerado "fiel", acaba-se considerando-a coerente. A cena do balcão foi toda reestruturada para dar ênfase a pontos considerados importantes no decorrer do diálogo, como, por exemplo, a evocação ao rouxinol, o qual está presente tanto no clássico tradicional como no criado pela Turma da Mônica, apenas contendo abordagens distintas.

No texto-base, o rouxinol aparece no Ato III, Cena $\mathrm{V}$, ao passo que no texto dramatúrgico de Yara Maura Silva, vemos uma prosopopeia do rouxinol, o qual entra em cena para realçar que ainda está de noite e que já está afastando-se do ninho, ou seja, quando raiar o dia, ele irá embora. No espetáculo infantil, essa personificação do rouxinol se concretiza pela interpretação do Cebolinha por meio da onomatopeia "piu", para reforçar que ainda está no período noturno, cujo entendimento faz o Senhor Capuleto retornar e dormir um pouquinho mais. No texto de Shakespeare, ele aparece somente para acentuar ou não a carga dramática da noite que Romeu e Julieta passaram juntos.

Mostrando o quanto a genialidade de Yara Maura realça o caráter trágico e, de forma mais presente, o cômico, essa adaptação paródica pode ser um incentivo à criança conhecer a obra shakespeariana, de modo que essa leitura permaneça na sua fase juvenil e na adulta, marcada com criatividade e as peripécias que permeiam as narrativas da Turma da Mônica há gerações, suscitando novas paródias e recriações para a criança que queira adentrar no universo do teatro.

\section{Considerações finais}

William Shakespeare é considerado um dos dramaturgos mais importantes da história ocidental e dentre suas peças, Romeu e Julieta se destaca pela exploração de emoções e a própria atemporalidade, sendo veiculada por muitas gerações, porém, o conteúdo de suas obras, devido à densidade e complexidade dos personagens, demanda uma mediação adulta. 
Traduzir intersemioticamente não significa apenas transformar uma obra-prima em outra obraprima. É um processo que tem como intuito provocar o leitor, de modo que ele venha a conhecer e ler o autor e sua produção literária, e que essa promoção do autor não é gratuita ou fortuita, pois sempre estamos nos deparando e encontrando vestígios das obras que fazem parte da nossa estante de conhecimento de mundo. Entendemos, como diz Umberto Eco (1991), que a poética de uma obra em movimento proporciona um novo desfrute do artista pelo espectador, no sentido de que sua obra artística, ao adentrar uma nova temporalidade, amplia e suscita aos pesquisadores problemas de natureza prática, estabelecendo novas comunicações e a dialética entre a contemplação e o uso de uma obra de arte.

Portanto, traduzir "uma obra para determinado público não deve caracterizar um procedimento condenável em si mesmo" (FARIA, 2008, p. 36), devendo, antes, ser objeto de análise, tendo sempre 0 objetivo dos destinatários para os quais foi pensado e, com base nisso, emitir uma crítica construtiva. Despertar o riso no leitor/espectador é um trabalho árduo e inteligente, mas quando o objeto de pesquisa é uma obra estrangeira, o problema aumenta, pois cabe ao responsável em lidar com esse texto manter as características e motivações do texto-base, a fim de se tornarem risíveis para um determinado público.

O que a análise realmente demonstra é que a leitura dramática dos clássicos pode ser direcionada a um espectador infantil, como é o caso da tradução da peça trágica para a televisão e em sua adaptação dramatúrgica. Assim como Shakespeare recriou suas fontes de Romeu e Julieta, Yara Maura Silva recriou o dramaturgo inglês para as crianças.

Pensando no conceito de tradução adotado neste trabalho, podemos pontuar que houve uma tradução de uma mídia a outra - do teatro para a televisão -, promovendo o condensar do texto e alterações para melhor atender às expectativas de um público totalmente alheio a Shakespeare, como também reformular de forma leve e cômica um texto denso por meio de apagamento e a omissão de alguns diálogos para facilitar a compreensão do neoleitor, sem prejudicá-lo na compreensão do drama de Romeu e Julieta.

Se partimos do pressuposto de que a tradução intersemiótica de Shakespeare voltada ao público infantil fosse considerada menor - tal como tem sido a ampla discussão tanto sobre adaptações literárias como sobre literatura infantil -, mesmo se houvesse uma dramaturgia infantil na época renascentista, não seria possível afirmar que a tradução interlinguística de um texto infantil brasileiro equivale ao texto-base inglês, por razões como o cognitivo, a mediação adulta e a própria concepção do indivíduo criança para ser um leitor de um texto linguisticamente denso e elaborada por/para adultos.

\section{Referências}

BALOGH, Anna Maria. Conjunções - disjunções transmutações: da literatura ao cinema e à TV. São Paulo: Annablume/ECA-USP, 1996.

BENDER, Ivo. Comédia e riso: uma poética do teatro cômico. Porto Alegre: Editora da UFRGS/EDPUCRS, 1996.

BERGSON, Henri. O Riso - Ensaio sobre o significado do cômico. Tradução de Maria Adriana Camargo Cappello. Introdução de Débora Cristina Morato Pinto. São Paulo: Edipro, 2018.

CAMPOS, Flávio. Roteiro de cinema e televisão: a arte e a técnica de imaginar, perceber e narrar uma estória. 1 reimp. da 2 ed revista. Rio de Janeiro: Zahar, 2019.

CARDWELL, Sarah. Adaptation Studies Revisited: Purposes, Perspectives, and Inspiration. In: LEV, Peter; WELSH, James Michael (eds). The Literature/film Reader: Issues of Adaptation. Lanham/Maryland: Scarcecrow Press, 2007a, p. 5163.

CARDWELL, Sarah. Literature on the small screen: television adaptations. In: CARTMELL, Deborah; WHELEHAN, Imelda (eds). The Cambridge Companion to Literature on Screen. Cambridge: Cambridge University Press, 2007b, p. 181-195.

ECO, Umberto. Obra aberta. Tradução de Giovanni Cutolo. São Paulo: Perspectiva, 1991.

ESSLIN, Martin. The Age of Televison. New Brunswick/London: Transaction Publishers, 2002. 
FARIA, Gentil de. As primeiras adaptações de Robinson Crusoe no Brasil. Revista Brasileira de Literatura Comparada. São Paulo, n.13, p.27-55, 2008.

GUIMARÃES, Hélio de Seixas. O romance do século XIX na televisão: observações sobre a adaptação de Os Maias. In: PELLEGRINI, Tânia et. al. Literatura, cinema, televisão. São Paulo: Senac/ Instituto Itaú Cultural, 2003, p. 91-114.

GUIMARÃES, Hélio de Seixas. Literatura em televisão: uma história das adaptações de textos literários para programas de TV. 1995. $217 \mathrm{f}$. Dissertação (Mestrado em Teoria e História Literária) Instituto de Estudos da Linguagem, Universidade Estadual de Campinas, Campinas, 1995.

HUTCHEON, Linda. Uma teoria da adaptação. Tradução de André Cechinel. Florianópolis: Editora da UFSC, 2011.

HUTCHEON, Linda. Uma teoria da paródia. Tradução de Teresa Louro Péres. Lisboa: Edições 70, 1985.

MAGALDI, Sábato. Iniciação ao teatro. São Paulo: Editora Ática, 1994.

MIRANDA, Célia Arns. A música como enquadramento épico no Otelo do Folias d'Arte. In: CONGRESSO INTERNACIONAL DA ABRALIC, XI., 2008. São Paulo. Anais... São Paulo: ABRALIC, 2008. p. 3-9.

PAVIS, Patrice. A análise dos espetáculos. Tradução de Sérgio Sávia Coelho. São Paulo: Perspectiva, 2003

PAVIS, Patrice. Dicionário de Teatro. 3aㅗ edição. Tradução de Sérgio Sálvia Coelho e Revisão de Marilena Vizentin. São Paulo: Editora Perspectiva, 2015.

PASSOS, Marie-Hélène Paret. Da crítica genética à tradução literária: uma interdisciplinaridade. São Paulo: Editora Horizonte, 2011.

RESENDE, Aimara da Cunha. Shakespeare na Televisão Brasileira. In: CAMATI, Anna Stegh; MIRANDA, Célia Arns de (orgs). Shakespeare sob múltiplos olhares. $2^{\underline{a}}$ ed. Curitiba: Editora da UFPR, 2016, p. 175-201.

SANFELICI, Aline Mello. Uma tragédia divertida: Rei Lear para crianças. Scripta Uniandrade, Curitiba, v. 14, n. 2, p. 148-169, 2016.

SCHAFER, Garnet Irene. A television adaptation of Romeo and Juliet by William Shakespeare. 1966. 115f. Thesis (Master in Arts). Department of Television and Radio, Michigan State University, Michigan, 1966.
SHAKESPEARE, William. Romeu e Julieta. Tradução de Bárbara Heliodora. Rio de Janeiro: Lacerda Editores, 1997.

SILVA, Yara Maura. Mônica e Cebolinha no Mundo de Romeu e Julieta. In: NISKIER, Arnaldo (org). A Magia do Teatro Infantil. Rio de Janeiro: Edições Consultor, 1988, p. 132-147.

VOLOŠINOV, Valentin N. Appendix I: Discourse in Life and Discourse in Art (Concerning Sociological Poetics). In: VOLOŠINOV, Valentin N. Freudianism: A Marxist Critique. Translated by I. R. Titunik and edited in collaboration with Neal H. Bruss. New York/San Francisco/London: Academic Press, 1976, p. 93-116.

ZILBERMAN, Regina. Teatro para crianças jovens: questões históricas e caminhos criativos. In: GRAZIOLI, Fabiano Tadeu (org). Teatro infantil: história, leitura e propostas. Curitiba: Editora Positivo, 2015, p. 15-29.

\section{COMO CITAR ESSE ARTIGO}

LUIZ, Tiago Marques; GRAZIOLI, Fabiano Tadeu. Romeu e Julieta para crianças: tradução intersemiótica do texto dramatúrgico no espetáculo Mônica e Cebolinha no mundo de Romeu e Julieta. Signo, Santa Cruz do Sul, v. 46, n. 87, sep. 2021. ISSN 1982-2014. Disponível em: $<$ https://online.unisc.br/seer/index.php/signo/article/vie $w / 16650>$.

doi:https://doi.org/10.17058/signo.v46i87.16650. 